release of $\mathrm{N}$ from the organic soils. The $\mathrm{C}: \mathrm{N}$ ratio was slightly higher in LD, and the low base growth and high response to $\mathrm{N}$ fertiliser is evidence of N limitation. However, it does not appear that the slight difference in C: $\mathrm{N}$ could fully explain the differences in $\mathrm{N}$ response between the two sites.

\section{Conclusions}

These findings indicate that farmers on less developed peat have lower base growth but can expect greater yield benefits from larger applications of $\mathrm{N}$ fertiliser Farms with WD soils, similar to those here, can expect efficient pasture yield increases in the spring from rates of $25 \mathrm{~kg} \mathrm{~N} / \mathrm{ha}$. It should be noted that the environmenta consequences of increased applications of $\mathrm{N}$ fertiliser have not been assessed in this study.

\section{AKNOWLEDGEMENTS}

This project has been funded by the Ministry for Primary Industries through the Sustainable Farming Fund (project \# 408101), and by Ballance AgriNutrients, Waikato Regional Council and New Zealand dairy farmers through DairyNZ. The authors would also like to thank Harry Rich of Orini, and Brett and Rache Gordon of Eureka for their cooperation, engagemen and use of their properties for these experiments.

\section{REFERENCES}

Baars, J.A.; O'Conner, M.B.; Ledgard, S.F.; Wallace, R.D. 1989. Nitrogen fertiliser use in intensive bull beef production on peat soils in the Waikato. pp. 28 36. In: Nitrogen in New Zealand Agriculture an Horticulture. Eds. White R.E.; Currie L.D. Occasional Report No 3, Fertiliser and Lime Research Centre, Massey University.
Ball, P.R.; Field, T.R.O. 1982. Responses to nitrogen as affected by pasture characteristics, season, and grazing management. pp. 45-64. In: Nitrogen fertilisers in New Zealand agriculture. Ed. Lynch, P.B. New Zealand Institute of Agricultural Science, Wellington.

Holden, J.; Evans, M.G.; Burt, T.P.; Horton, M. 2006. Impact of land drainage on peatland hydrology. Journal of Environmental Quality 35: 1764-1778.

Kelliher, F.M.; van Koten, C.; Lindsey, S.B.; Wise, B.; Rys, G. 2016. Nitrous oxide emissions from drained peat soil beneath pasture. New Zealand Journal of Agricultural Research 59: 363-376.

Nieveen, J.P.; Campbell, D.I.; Schipper, L.A.; Blair, I.J. 2005. Carbon exchange of grazed pasture on a drained peat soil. Global Change Biology 11: 607618.

O’Connor, M.B.; Longhurst, R.D.; Johnston, T.J.M.; Portegys, F.N. 2001. Fertiliser requirements for peat Zealand Grassland Association 63: 47-51.

chipper, L.A.; McLeod, M. 2002. Subsidence rates and carbon loss in peat soils following conversion to pasture in the Waikato Region, New Zealand. Soil Use and Management 18: 91-93.

Shepherd, M.; Ghani, A.; Rajendram, G.; Carlson, B.; Pirie, M. 2015. Soil total nitrogen concentration explains variation in pasture response to spring nitrogen fertiliser across a single farm. Nutrient Cycling in Agroecosystems 101: 377-390.

an der Elst, F.H. 1980. Development of peat soils for agriculture. Chapter 4. In: Soil Groups of New Zealand, Part 4, Organic Soils. Eds. van der Elst, F.H.; Kinloch, D. New Zealand Society of Soil Science. Wellington, New Zealand.

\title{
Soil inorganic nitrogen in spatially distinct areas within a commercial dairy farm in Canterbury, New Zealand
}

D.C. EKANAYAKE ${ }^{1}$, J.L. OWENS ${ }^{2}$, S. HODGE ${ }^{2}$, J.A.K. TRETHEWAY' ${ }^{1}$, R.L. ROTEN ${ }^{1}$, M. WESTERSCHULTE ${ }^{1}$, S.BELIN ${ }^{1}$, A. WERNER ${ }^{1}$ and K. CAMERON ${ }^{1}$ Lincoln Agritech Ltd., PO Box 69 133, Lincoln, Canterbury 7640, New Zealand ${ }_{2}^{2}$ Agriculture and Life Sciences Faculty, PO Box 84, Lincoln University, Lincoln, New Zealand dinanjana.ekanayake@lincolnagritech.co.nz

\section{Abstract}

For precision nitrogen $(\mathrm{N})$ fertilisation of grazed dairy paddocks, soil $\mathrm{N}$ distribution needs to be quantified. It is expected that farm infrastructure will affect inorganic- $\mathrm{N}$ distribution due to its influence on cow grazing behaviour. Surface soil from four spatially distinct areas (main gate, water troughs, non-irrigated and the remaining pasture) was analysed for soil ammonium- $\mathrm{N}$ $\left(\mathrm{NH}_{4}^{+}-\mathrm{N}\right)$ and nitrate- $\mathrm{N}\left(\mathrm{NO}_{3}{ }^{-} \mathrm{N}\right)$ from three paddocks (180 soil samples) on an irrigated commercial dairy farm in Canterbury, New Zealand. Variation between paddocks was higher for $\mathrm{NO}_{3}^{-}(\mathrm{P}<0.001)$ than for $\mathrm{NH}_{4}^{+}(\mathrm{P}=0.52)$. Differences between spatially distinct areas were detected for $\mathrm{NH}_{4}^{+}(\mathrm{P}<0.001)$ but not for $\mathrm{NO}_{3}^{-}(\mathrm{P}=0.37)$, though there was variation in $\mathrm{NO}_{3}$ with distance from the gates and troughs. This study demonstrates methods for classifying spatially distinct areas of grazed pasture to quantify their influence on inorganic-N distribution. Further research is required to better understand variability.

Keywords: nitrogen, spatial nitrogen distribution, distinct areas

\section{Introduction}

Use of centre pivot irrigation and repetitive mineral $\mathrm{N}$ fertiliser applications on grazed paddocks have increased to support the intensification of dairy production in New Zealand (Foote et al. 2015). Precision fertilisation can exclude high $\mathrm{N}$ areas, reduce fertiliser amounts without sacrificing yields (Diacono et al. 2013), and reduce $\mathrm{NO}_{3}^{-}$leaching (Foote et al. 2015). Strategies for precision fertilisation within cattle-grazed paddocks differ from cropped areas due to heterogeneous grazing behaviours of cattle (Sanderson et al. 2010).

Cattle grazing patterns are spatially uneven, as cows can spend $\sim 50 \%$ of their time within $13 \%$ of the paddock (Hunt et al. 2007). Repeated grazing results in spatially random excreta distribution in the paddock (White et al. 2001), and rates of soil $\mathrm{N}$ accumulation are affected by stocking rate, grazing intensity and rotation (White et al. 2001; Hunt et al. 2007; Putfarken et al. 2008). However, cattle are known to frequent reas around farm infrastructure like water troughs, ences and shelter belts (White et al. 2001; Hunt et al. 2007; Putfarken et al. 2008), which may result in higher soil $\mathrm{N}$ in these areas. Identifying spatially distinct areas based on the orientation of farm infrastructures (i.e. water troughs, fences, shelter belts), may provide a way to characterise spatial $\mathrm{N}$ distribution around a grazed dairy pasture.

A strategy is needed to quantify the spatial distribution of $\mathrm{N}$ within intensively grazed pastures and to related farm infrastructure to develop precision ertiliser schemes. The objective of this paper was to test a methodology to delineate farm infrastructure related spatially distinct areas around a typical New Zealand dairy farm, and to quantify spatial distribution of $\mathrm{NH}_{4}^{+}-\mathrm{N}$ and $\mathrm{NO}_{3}^{-}-\mathrm{N}$.

\section{Materials and methods}

\section{Experimental site}

The site was an irrigated commercial dairy farm in Rolleston $\left(43.56750^{\circ} \mathrm{S}, 172.32334^{\circ} \mathrm{E}\right)$, Canterbury, New Zealand. The soil was a stoneless, free-draining Lismore silt loam (Pallic Firm Brown Soil, Hewitt 2010). The farm stocking density was 3.6 cows/ha for a herd of 630 Friesians. Cows were rotationally grazed on perennial ryegrass (Lolium perenne)/ white (Len The days for March, April and May, respectively, during 2017) with supplementary feed provided as required. Tota broadcast N-fertiliser was $190 \mathrm{~kg} \mathrm{~N} / \mathrm{ha}$ from September 2016 to April 2017, including $50 \mathrm{~kg} / \mathrm{ha}$ of 'SustaiN $25 \mathrm{~K}$ ' (at $23 \% \mathrm{~N}$ ) fertiliser after each grazing. Pasture irrigation averaged $3 \mathrm{~mm} / \mathrm{ha} /$ day from October 2016 to March 2017.

\section{Soil Sampling}

Three paddocks (coded 17, 19 and 33), each 5.1-5.5 ha and located in the centre pivot irrigation area, were selected for soil sampling. Each paddock included main gate, a water trough, and low producing (nonirrigated) area, that were spatially distinct.

Different sampling regimes were used for each distinct area of the paddock to obtain spatially 


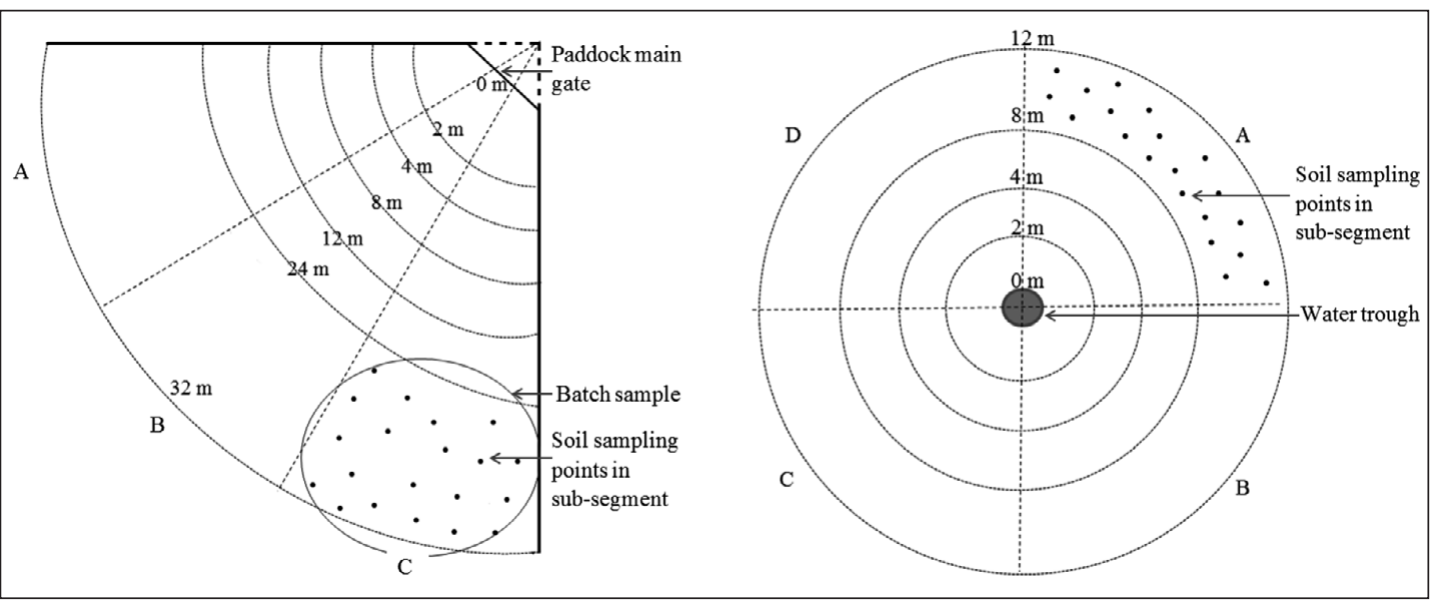

Figure 1 Illustration of sampling procedure at paddock main gate (left) and around water trough (right).

representative samples. Areas around the main gates and water troughs were sub-divided into sampling zones using a radial grid system (Figure 1). Soil samples were obtained at the main gate in an arc divided into three segments, extending from the gate to the main paddock area at increasing distances (Figure 1). Similarly, circular rings divided into four equal segments were subdivided with distances marked at 2, 4, 8 and $12 \mathrm{~m}$ from the water trough (Figure 1). The non-irrigated areas were identified as having lower pasture density and an atypical canopy cover compared to the inigated reas. Using in the paddocks were measured and divided into ten equal segments. The whole paddock area was divided into nine rectangular segments, excluding non-irrigated areas. A $50 \mathrm{~m}$ buffer zone (Sanderson et al. 2010) was allocated away from the gates, water troughs and nonirrigated areas when sampling the remainder of the paddock

In April 2017, $15 \mathrm{~cm}$ deep soil cores were collected from within each spatially distinct area, 4 to 12 days after grazing and before $\mathrm{N}$ fertilisation. Twenty spatially random soil cores were collected within each sub-segment, and were combined into one sample representative of that sub-segment (Figure 1). For each paddock, there were a total of 18 samples taken nea the main gate, 16 samples near the water troughs, 10 samples in the non-irrigated and 9 samples from the remainder. Visible urine and dung patches were avoided luing soil core collection. All samples were ket in coling soll core collection. All sampes were 1 a freezer $\left(0^{\circ} \mathrm{C}\right)$ for laboratory storage before analysis.

\section{Soil analysis}

To measure soil inorganic- $\mathrm{N}\left(\mathrm{NO}_{3}^{-}-\mathrm{N}, \mathrm{NH}_{4}{ }^{+} \mathrm{N}\right)$ field-moist soil was sieved $(<5 \mathrm{~mm})$ and $5 \mathrm{~g}( \pm 0.05$ g) subsamples were combined with $25 \mathrm{ml}$ of $2 \mathrm{M} \mathrm{KCl}$ The samples were then centrifuged at $4000 \mathrm{rpm}$ for 10 minutes before filtering through $110 \mathrm{~mm}$ "Advantec" $5 \mathrm{C}$ filter paper. Extracts were analysed colorimetrically using a Flow Injection Analyser (FIAstar 5000 Analyser, FOSS, Centre for Soil and Environmental Research, Lincoln University) within 48 hours of extraction. Extracted samples were stored at $4{ }^{\circ} \mathrm{C}$. Gravimetric soil moisture was determined by placing $20 \mathrm{~g}$ of field moist soil in a paper container (weight of paper container + 48 hours. Inorgan to mass of inorganic-N per mass of soil gravimetrically.

Analyses were performed using Genstat v16 (VSN International Ltd., UK). Soil $\mathrm{NO}_{3}^{-}$and $\mathrm{NH}_{4}^{+}$ concentrations were transformed as $\log _{10}(x)$ before analysis, to account for variation between paddocks and different areas were compared using Residual Maximum Likelihood (REML) mixed models, assigning area as a fixed factor and paddock as a random factor. These analyses included all the samples from non-irrigated areas, those samples within $12 \mathrm{~m}$ from a gate or trough and the remainder of the paddock. Differences between areas were identified using estimated Least Significance Difference (LSD) pairwise comparisons

The data describing how $\mathrm{N}$-concentration varied as a finction of distance fom gates or trough examined separty for each paldock uring were ANOVA. These nova. These analyses also included data from the normal paddock area of each paddock to represent background levels of $\mathrm{NO}_{3}^{-}$and $\mathrm{NH}_{4}^{+}$. Groups of samples significantly different from the background levels were identified using Fisher's unprotected LSDs $(\mathrm{P}<0.05)$ and mixed for one hour on a "Ratek" Platform Mixer. mist sil) and oven- $105^{\circ} \mathrm{C}$ for between 24 to

\section{Statistical analysis} unbalanced sampling design. $\mathrm{N}$-concentrations in the

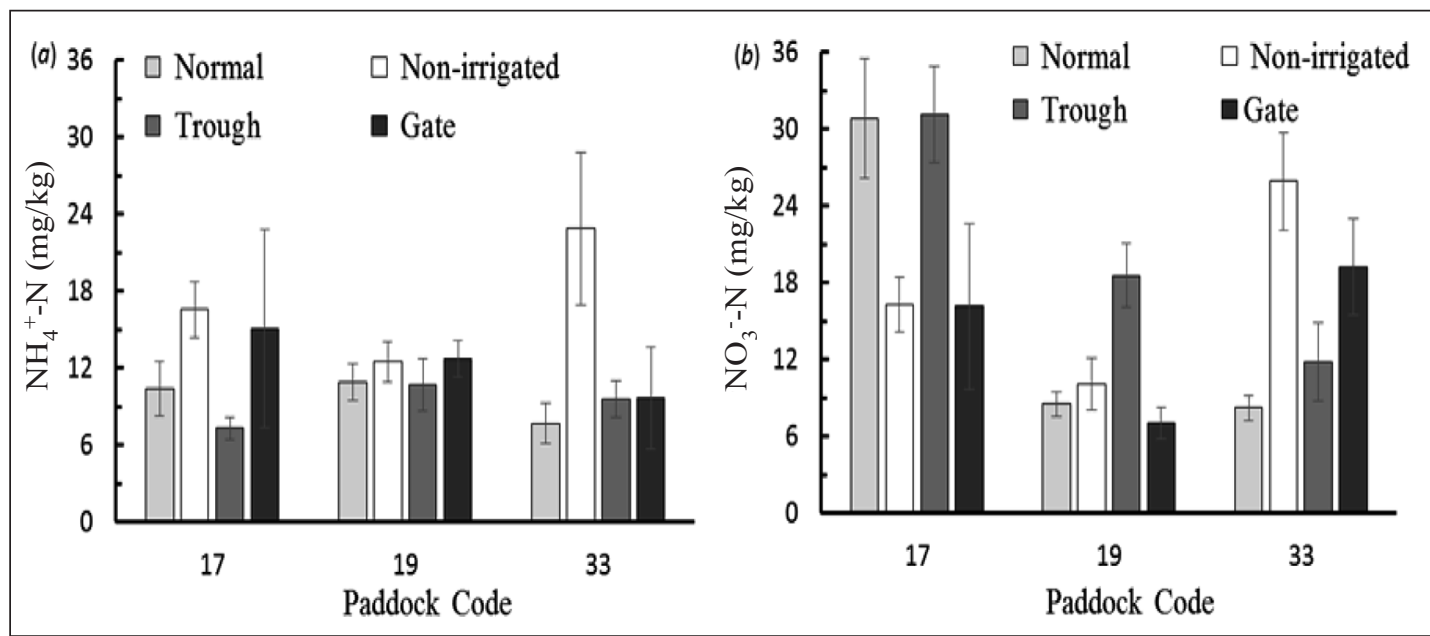

Figure 2 Soil inorganic-N concentration in different areas of the paddocks; (a) $\mathrm{NH}_{4}{ }^{+}-\mathrm{N}(\mathrm{mg} / \mathrm{kg})\left(\right.$ b) $\mathrm{NO}_{3}-\mathrm{N}(\mathrm{mg} / \mathrm{kg})$.

\section{Results}

Geral trends of inorganic-N

Both $\mathrm{NH}_{4}^{+}$and $\mathrm{NO}_{3}^{-}$concentrations were highly variable across the three paddocks. Overall mea $\mathrm{NH}_{4}{ }^{+}-\mathrm{N}$ concentrations were $11.9 \mathrm{mg} / \mathrm{kg}$ soil, but had a 19 -fold difference between the minimum $(3.5 \mathrm{mg} / \mathrm{kg})$ and maximum value $(65.9 \mathrm{mg} / \mathrm{kg})$. Similarly, $\mathrm{NO}_{3}{ }^{-}$had a mean concentration of $29.3 \mathrm{mg} / \mathrm{kg}$ but a wide (43fold) range, from $1.3 \mathrm{mg} / \mathrm{kg}$ to $54.5 \mathrm{mg} / \mathrm{kg}$.

Distribution of inorganic- $\mathrm{N}$ in different areas of the paddocks

When comparing the means between spatially distinct areas within paddocks, there was considerable variation between paddocks for $\mathrm{NO}_{3}^{-}(\mathrm{P}<0.001)$, but not for $\mathrm{NH}_{4}^{+}(\mathrm{P}=0.52)$ (Figure 2). One paddock had relatively high $\mathrm{NO}_{3}$ - concentration in the non-irrigated area $(25.9$ $\mathrm{mg} / \mathrm{kg}+3.8)$. Over cong concentrations between the distinct areas $(\mathrm{P}<0.001)$. (Figher mean levels than the other three areas (Figure 2a). When comparing overall means, there was no evidence suggesting that $\mathrm{NO}_{3}{ }^{-}$differed systematically between different paddock areas $(\mathrm{P}=0.37)$. However, overall mean $\mathrm{NO}_{3}^{-}$concentration recorded in the remaining (normal) paddock area and trough area in one paddock were higher than in all other areas (Figure $2 b$ ).

\section{Distances from gates and water troughs}

There were no clear patterns in $\mathrm{NH}_{4}^{+}$concentrations with distance from water troughs or the main gates (data no shown). In paddocks 19 and 33, $\mathrm{NO}_{3}{ }^{-}$was higher closer to the troughs, and receded to concentrations similar to the normal paddock area by $\sim 8 \mathrm{~m}$ from the trough (Figure 3). In paddock 17 and 19, $\mathrm{NO}_{3}{ }^{-}$concentrations were lower closer to the gates, and gradually increased at distances away from the gates (Figure 3). In paddock $33, \mathrm{NO}_{3}^{-}$concentrations were high at $2 \mathrm{~m}$ from the gates, before quickly decreasing at $4 \mathrm{~m}$ and increasing again at $12 \mathrm{~m}$ then gradually decreasing again at greater distances from the gates.

\section{Discussion}

The low variability in $\mathrm{NH}_{4}^{+}$between spatially distinct areas, and between paddocks (Figure 2), suggests nitrification rates from $\mathrm{NH}_{4}^{+}$to $\mathrm{NO}_{3}^{-}$(Sahrawat 2008) were relatively consistent. The one exception was the high mean $\mathrm{NH}_{4}^{+}$in the non-irrigated areas of paddock 33 which was unshaded, unlike paddocks 17 and 19 which were partially shaded by trees. The lack of shade in paddock 33 may have resulted in drier soil, lower nitrification rates, and higher $\mathrm{NH}_{4}^{+}$.

Greater soil nutrients from excreta depositions near gates and water troughs have been noted (Wilkinson

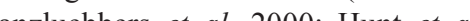
2007; Putfarken et al. 2008), but the current study showed that $\mathrm{NO}_{3}^{-}$in the gates and trough areas were highly variable (Figure 2). This variability may be related to the trends observed in $\mathrm{NO}_{3}{ }^{-}$with distance from gates and troughs (Figure 3). Future studies should reconsider delineation boundaries beyond 8 $\mathrm{m}$ around troughs, where $\mathrm{NO}_{3}^{-}$was not higher than the surrounding paddock. However, $\mathrm{NO}_{3}^{-}$around the waldock up until $32 \mathrm{~m}$, suggesting that the affected area may extend beyond the current delineation. The $\mathrm{NO}_{3}^{-}$variability may be due to gradients in factors like soil moisture, which affect rates of nitrification and denitrification (Davidson \& Verchot 2000), and therefore $\mathrm{NO}_{3}$ concentrations

The studied areas, especially those around gates and troughs, had almost no growth of pasture biomass, 


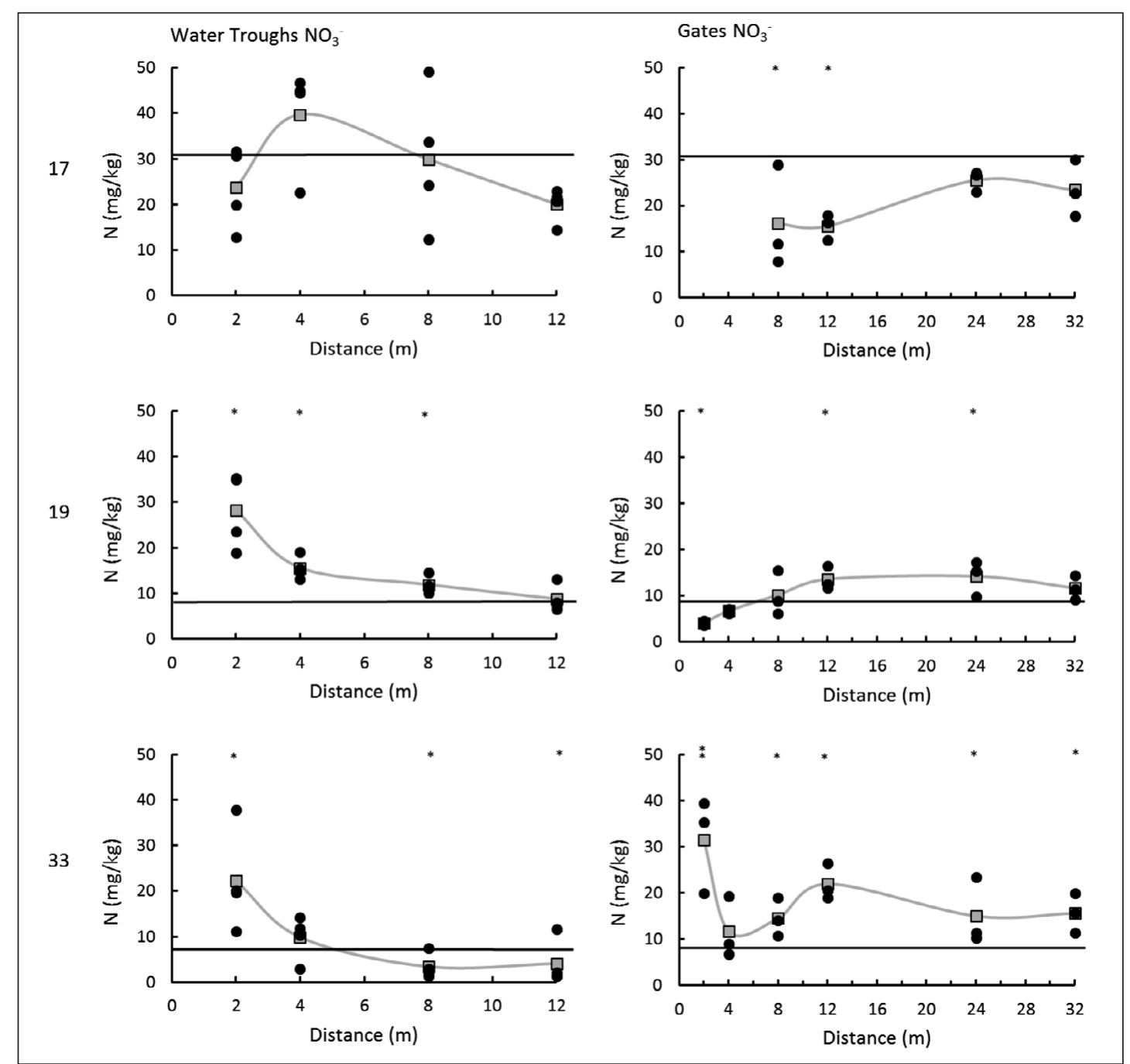

\section{ACKNOWLEDGEMENTS}

This work was funded through a grant from The Ministry of Business Innovation and Employment under project, Optimum N - Nitrogen Sensing and Management (contract No.: CONT-29854-BITR_LVL). We would like to express special thanks to the Centre for Soil and Environmental Research, Lincoln University for soil sampling and speedy analysis.

\section{REFERENCES}

Davidon, E.A. Verchot, L.V. 2000. Testing the hole-in-the-pipe model of nitric and nitrous oxide emissions from soil using the TRAGNET database. Global Biogeochemical Cycles 14: 1035-1043.

Diacono, M.; Rubino, P.; Montemurro, F. 2013. Precision nitrogen management of wheat. A review. Agronomy for Sustainable Development 33: 219-241.

Foote, K.J.; Joy, M.K.; Death, R.G. 2015. New Zealand dairy farming: milking our environment for all its worth. Environmental Management 56: 709-720.

Franzluebbers, A.J.; Stuedemann, J.A.; Schomberg, H.H. 2000. Spatial distribution of soil carbon and nitrogen pools under grazed tall fescue. Soil Science Society of America Journal 64: 635-639.

Hewitt, A.E. 2010. New Zealand soil classification. Landcare Research Science Series No, 1, 3rd Ed Manaki-Whenua Press, Lincoln, New Zc

Hunt, L.P.; Petty, S.; Cowley, R.; Fisher, A.; Ash, A.J.; MacDonald, N. 2007. Factors affecting management of cattle grazing distribution in northern Australia: preliminary observations on the effect of paddock size and water points. The Rangeland Journal 29 : $169-179$

Johnson, R.J.; McCallum, D.A.; Thomson, N.A 1993. Pasture renovation after winter pugging damage. Proceedings of the New Zealand Grassland Association 55: 143-146.

Putfarken, D; Dengler, J.; Lehmann, S.; Härdtle, W. 2008. Site use of grazing cattle and sheep in a lat ef Applied Animal Behaviour Science 111: 54-67.

Sanderson, M.A.; Feldmann, C.; Schmidt, J.; Herrmann, A.; Taube, F. 2010. Spatial distribution of livestock concentration areas and soil nutrients in pastures. Journal of Soil and Water Conservation 65: 180-189. Sheath, G.W.; Carlson, W.T. 1998. Impact of cattle treading on hill land. 1. Soil damage patterns and pasture status. New Zealand Journal of Agricultural Research 41: 271-278.

Sahrawat, K.L. 2008. Factors affecting nitrification in soils. Communications in Soil Science and Plant Analysis 39: 1436-1446

White, S.L.; Scheffield, R.E.; Washburn, S.P.; King, L.D.; Green, Jr. J.T. 2001. Spatial and time distribution of dairy cattle excreta in an intensive pasture system. Journal of Environmental Quality 30: $2180-2187$

Figure 3 Nitrate $\left(\mathrm{NO}_{3}{ }^{-}\right)$concentrations (individual samples in black, mean in grey, and a grey smooth line through the means) with the distance from water trough (left) and distance from the main gate (right). The solid black line represents level of $\mathrm{N}$ in

likely due to compaction from cattle (Johnson et al. 1993; Sheath \& Carlson 1998). Inclusion of compaction in future studies may help explain occurrences of inorganic-N variability. As the whole paddock received a uniform $\mathrm{N}$ fertiliser application and the studied areas did not show significant differences in the soil $\mathrm{N}$ pols, untilised $\mathrm{N}$ fertiliser has to be considered as work provide a baline for the develophent of a spatially variable rate fertiliser application system, as a system for efficiently evaluating soil $\mathrm{N}$ in a grazed paddock will be required. Future iterations of the work can begin to try to couple soil $\mathrm{N}$ distribution around farm infrastructure with other factors that are more quickly measured using remote sensors, such as vegetation greenness or density.

\section{Conclusions}

Low $\mathrm{NH}_{4}{ }^{+}$variability was observed in all areas expect the non-irrigated areas. High variability in $\mathrm{NO}_{3}{ }^{-}$ proximate to gates and troughs was observed with variability subsiding at different distances away from the infrastructure. Quantifying inorganic-N spatial variability on irrigated dairy farms may help reduce $\mathrm{N}$ fertiliser applications to reduce $\mathrm{N}$ lost as pollution, without affecting plant yields. Extended studies are desirable to confirm the influence of spatially distinct areas around farm infrastructure. 